\title{
Granulometric composition research of mine rocks as a material for backfilling the mined-out area in coal mines
}

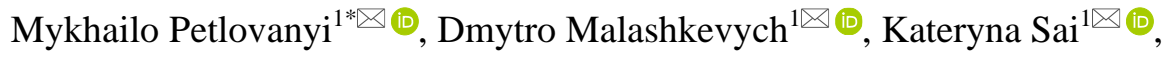 \\ Ievgeniia Bulat ${ }^{2 \otimes(1)}$, Vasyl Popovych ${ }^{3 \otimes}$ (1) \\ ${ }^{1}$ Dnipro University of Technology, Dnipro, 49005, Ukraine \\ ${ }^{2}$ Prydniprovsky Scientific Center of the National Academy of Sciences of Ukraine and the Ministry of Education and Science of Ukraine, \\ Dnipro, 49000, Ukraine \\ ${ }^{3}$ Lviv State University of Life Safety, Lviv, 79007, Ukraine \\ *Corresponding author: e-mail petlyovany@ukr.net, tel.+380963194577
}

\begin{abstract}
Purpose. Determination of the granulometric characteristics and loosening coefficient of mine rocks formed during stope operations from undercutting the bottom rocks as a potential backfill material based on a set of mine and laboratory research.

Methods. To do research, a complex methodology is used, which includes a photographic surveying the mass of destroyed rocks from undercutting the bottom rocks in mine conditions, digital processing and determining the granulometric composition in the software package, sampling the mine rocks at the surface complex, and reconstructing the granulometric composition, similar to the full-scale mine conditions in the laboratory. Sieve analysis, laboratory balance and laboratory container are used to determine the granulometric composition and loosening coefficient.

Findings. The dependence between the granulometric composition and loosening coefficient of rocks, which increases by $33 \%$ within fractions of $0-50 \mathrm{~mm}$ and by $8 \%$ within fractions of $50-140 \mathrm{~mm}$, has been revealed. It has been determined that the destroyed rocks in the face within fractions of $0-140 \mathrm{~mm}$ have a bulk density of $1.28 \mathrm{~g} / \mathrm{cm}^{3}$, loosening coefficient of 1.7 , the voidness of and the maximum reserve for the backfill mass compaction with mine rocks is $41.9 \%$. An analytical assessment of the volumes of the formed cavities of the mined-out area in the longwall face and gobed mine workings, as well as the prospects and completeness of their filling with mine rocks have been performed.

Originality. It has been determined that the loosening coefficient of mine rocks destroyed in the stope face by KA-200 shearer changes according to the logarithmic dependence on their granulometric composition. This makes it possible to control the granulometric characteristics of the backfill material to achieve the maximum density of the backfill mass.

Practical implications. Further research can serve as a basis for determining the rational parameters for the formation and placement of backfill masses during complex-mechanized selective mining of coal seams using various methods of backfilling operations.
\end{abstract}

Keywords: mine rocks, rock undercutting, stope face, shearer, granulometric composition, loosening coefficient, underground cavities, backfill material

\section{Introduction}

In developed countries, the rational use of natural resources is an important component during mining of various types of minerals, since environmental protection is the most important principle of modern society. Particular attention is paid to the coal mining industry, since the implementation of a number of technological mining processes has a negative impact on the natural environment for a number of factors. The latter include subsidence of the daylight surface in the absence of backfilling the mined-out area [1]-[3], accumula- tion of waste rock dumps and tailings over large areas, as well as atmosphere pollution with coalmine methane and products of blasting operations, pollution of surface water bodies with highly mineralized mine waters [4]-[6]. The coal mining industry is still an important component of the economy in a number of countries, such as Poland, Russia, Ukraine, USA, China, India, where coal is a raw material for energy and metallurgy [7]-[9].

The most serious technogenic impacts of mining operations are on the subsoil and the daylight surface. When minerals are mined from the subsoil, cavities are formed. Then,

Received: 12 February 2021. Accepted: 7 December 2021. Available online: 24 December 2021

(C) 2021. M. Petlovanyi, D. Malashkevych, K. Sai, Ie. Bulat, V. Popovych

Published by the Dnipro University of Technology on behalf of Mining of Mineral Deposits. ISSN 2415-3443 (Online) | ISSN 2415-3435 (Print)

This is an Open Access article distributed under the terms of the Creative Commons Attribution License (http://creativecommons.org/licenses/by/4.0/),

which permits unrestricted reuse, distribution, and reproduction in any medium, provided the original work is properly cited. 
as a result of stresses redistribution in the mass, the processes of rock displacement occur, disrupting the hydrogeological regimes of groundwater [10], [11]. And, even worse, a shift trough is formed on the daylight surface.

Currently, Western Donbas plays a decisive role in the development of the coal-mining industry and the state economy of Ukraine. More than $70 \%$ of all coal production in the country is provided by the coal-mining enterprises of this region, which are represented by 8 operating mines of PJSC "DTEK Pavlohradvuhillia" [12]-[14]. It is here that underground coal mining without the use of backfilling technologies has led to serious changes in the earth's surface (Bohdanivka town and Ternivka city). As a result of the earth's surface subsidence, the groundwater level has increased, which has led to water-logging and the formation of a flood zone with an area of about $17.0 \mathrm{~km}^{2}$. The depth of the groundwater level in the flooded areas ranges from 1.1 to $3.0 \mathrm{~m}$. The annual monitoring of the daylight surface and groundwater level has revealed that, compared to 2018, the earth's surface subsidence has increased by $0.15 \mathrm{~m} \mathrm{[15].}$ However, there are still no measures to combat floods. Also, waste in the form of waste rock dumps as a result of mining operations accumulates on the daylight surface in this area. Thus, during the industrial development of coal seams in the Western Donbas, 11 waste dumps were formed, in which more than 100 million tons of waste rocks with a total area of more than 200 hectares were accumulated [16].

It is possible to improve the ecological situation in coalmining regions through the development and implementation of environmental resource-saving mining technologies, one of which is the use of backfilling of the mined-out area. In world practice, mining technologies with backfilling of the mined-out area, as well as the method of disposal of the industrial waste, such as mine rocks, tailings, metallurgical slags, have proven high efficiency and environmental safety [17]-[19]. When developing valuable types of ore deposits, mining technologies with backfilling with paste or cemented rockfill have become widespread [20]-[22], since significant underground cavities are formed in the depths. When developing coal deposits, mining technologies with backfilling are rarely used. Their use is conditioned by the presence of medium-thick and thick coal seams, as well as the danger of the earth's surface failure during the extraction of reserves. In this case, mine rocks accumulated in the dumps, which are transported from the surface dumps to the mine, are used as a backfill material [23], [24].

Many teams around the world are developing "green" technologies for coal mining, aimed at reducing the volumes of waste generation and pollutant emissions into the atmosphere, as well as improving the energy quality of coal products. In particular, a number of publications in recent years have been devoted to improving the quality of mined coal and reducing its losses [25]-[27]. The works of the authors in [28], [29] are aimed at finding a more perfect technology for stope operations. In the works [30], [31], it is proposed to use the processes of underground rock mass enrichment. Particularly noteworthy is a number of works aimed at the development of advanced technologies of selective coal mining, excluding the dilution of coal by the rocks of undercutting during mining operations. In the case of selective mining of coal, the rocks of the coal seam bottom undercutting can be an effective backfill material. When developing an effective technology, it can be used for backfilling the mined-out area of the longwall face and mine workings gobed after its advance. Currently, new technological solutions are being developed for using the undercut rocks to backfill the mined-out area [2], [32].

For the development of a new advanced coal mining technology with backfilling or leaving the mine rocks in the mined-out area of mines, it is especially important to study the physical-mechanical properties of the backfill material in the process of its formation during mining, in particular, the granulometric characteristics. The granulometric composition of the backfill material during the formation of the backfill mass ensures its certain deformation and compression properties, the study of which is of priority importance.

Further, based on a complex of mine and laboratory research, the granulometric characteristics are determined of rocks formed in the process of stope operations from undercutting the bottom rocks as a potential material for backfilling. These studies will make it possible to determine the real granulometric composition and loosening coefficient of mine rocks, to assess the real volumes of possible placement of rocks in the mined-out area and gobed mine workings following the longwall face, as well as to substantiate the required productivity of the backfill equipment.

\section{Research methods}

\subsection{Brief description of the research object}

The research on granulometric characteristics of mine rocks obtained from undercutting the bottom rocks in longwall faces is conducted in the conditions of the Heroiiv Kosmosu Mine, PJSC "DTEK Pavlohradvuhillia". The extraction panels in the Heroiiv Kosmosu Mine are mined out to the rise of the seam in the direction of the main mine workings. The length of the extraction panels is $1000-1500 \mathrm{~m}$, and the length of the longwall faces is 200-250 m. The mining sites of the Heroiiv Kosmosu Mine are equipped with KD-80, KD-90, KD-99 mechanized complexes and KA-200 shearers, designed for the development of thin seams. The daily production of coal is in the range of 1500-2000 tons/day. The geological seam thickness is within $0.78-0.96 \mathrm{~m}$, and extracting seam thickness is 1.03-1.07 m. Bottom rocks are mainly represented by argillites and siltstones, the roof rocks - by argillites and sandstones. The category of roof rocks according to failure ability ranges from light to medium.

The 912 longwall face of $\mathrm{C}_{9}$ seam in the Heroiiv Kosmosu Mine of PJSC "DTEK Pavlohradvuhillia" has been chosen to study the granulometric composition of mine rocks. In the 912 longwall face, the extracting seam thickness averages $1.07 \mathrm{~m}$ with an average geological seam thickness of $0.95 \mathrm{~m}$. The structural column of the coal seam is shown in Figure 1. It is rather problematic to study the granulometric composition of mine rocks lying in the bottom of the seam, since a complete total extraction of the seam thickness is performed and it is not possible to obtain the volume of destroyed rocks without coal. At the time of the research, the mining of the 912 extraction pillar was completed with a longwall face, approaching the boundary of the protecting pillar of the main mine workings, and there were preparations for dismantling the mechanized complex. The KA-200 shearer performed removal of stripping over the seam bottom rocks to obtain an experimental volume of destroyed rocks. 


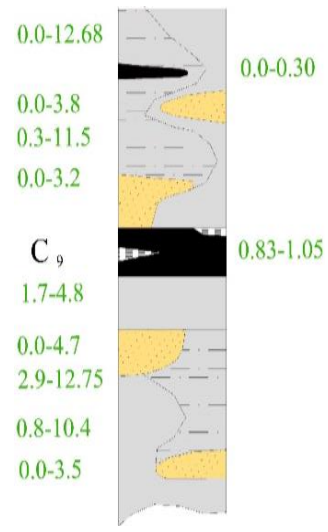

Figure 1. Structural column of coal seam C9

According to the mining-and-geological prediction of the 912 longwall face, dark gray, flat-lying hogbacked lamellar argillite occurs in the bottom of the seam. Below the bottom of the coal seam it has a lumpy texture and with carbonized detritus along the stratification. Physical-mechanical properties are given in Table 1.

Table 1. Physical-mechanical properties of argillite

\begin{tabular}{lc}
\hline \multicolumn{1}{c}{ Parameter } & Value \\
\hline Compression strength, $\mathrm{MPa}$ & $2.1-15.0$ \\
\hline Tensile strength, $\mathrm{MPa}$ & $1.2-1.7$ \\
\hline Humidity, \% & 4.0 \\
\hline Real density, g/cm ${ }^{3}$ & 2.32 \\
\hline Cutting resistance, $\mathrm{KN} / \mathrm{cm}$ & 1.7 \\
\hline Porosity, \% & 11.0 \\
\hline Adhesion coefficient, $\mathrm{MPa}$ & 3.6 \\
\hline Internal friction angle, deg. & 39 \\
\hline Elasticity modulus, $\mathrm{MPa}$ & 8300 \\
\hline Poisson's ratio & 0.32 \\
\hline
\end{tabular}

In the conditions of studied mine, the sources and balance of the generated volumes of waste rock and underground cavities in the course of mining operations have been previously studied in detail [33]. This study is a continuation of the studies noted above, in terms of determining the properties of mine rocks as a potential backfill material.

\subsection{Research on granulometric composition using information technology in mine conditions}

It is problematic to deliver experimental samples of destroyed rocks for laboratory research from the 912 longwall face to the surface. Therefore, it is decided to use information technology to determine the granulometric composition. Sampling of mine rocks for laboratory research is performed directly at the surface technological complex for sorting raw coal.

The photographic surveying of destroyed rocks is conducted on a belt conveyor of the 912 longwall face haulage roadway, since the surveying of destroyed rocks after the passage of the shearer is dangerous due to the possible failure of friable roof rocks into the stope face. The location and process of photographic surveying of the destroyed rocks is shown in Figure 2. Photographic surveying of the destroyed rock is made using a specialized explosion-proof camera of the mine occupational safety and health department. To determine the granulometric composition based on the results of surveying, specialized software WipFrag for scaling various images is used. To scale the rock fractions to the fullscale ones, a 1.0-meter tape measure is used as a reference, which is applied to the surface of the destroyed rock mass.

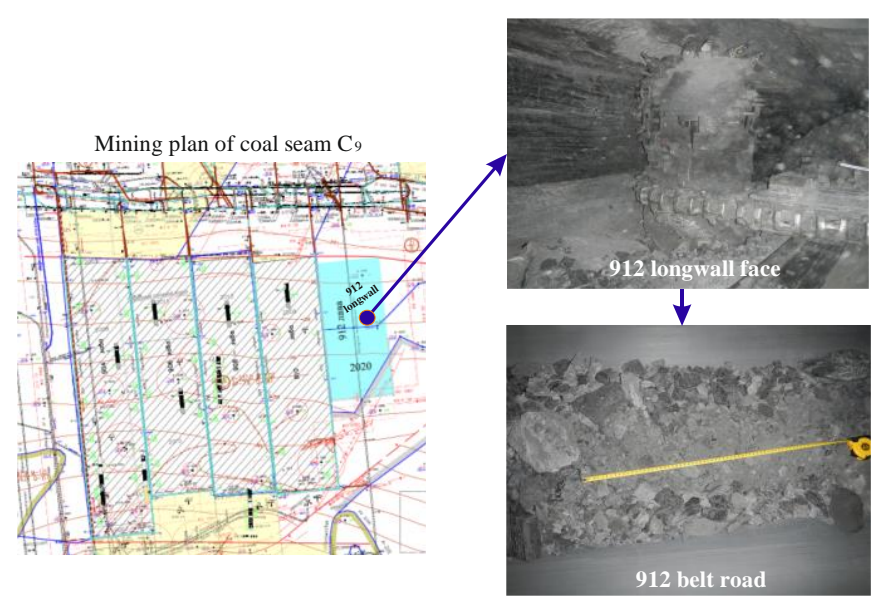

Figure 2. Schematic representation of the place for surveying the granulometric composition of the destroyed rocks

In the program, the size of the grid division into fractions is selected for the most correct delineation of the rock fractions, after which additional delineation of the fractions is performed manually (Fig. 3). After the stage of delineating the fractions, the program plots a curve of the granulometric characteristic of the destroyed rocks and data on the percentage of a certain rock fraction. Plotting of the granulometric characteristic curve using the software package makes it possible in laboratory conditions from the selected mine rocks to simulate and form the real granulometric composition of the seam bottom rocks destroyed by KA-200 shearer. The proposed research method is effective in a difficult situation associated with taking the real mine rock samples.

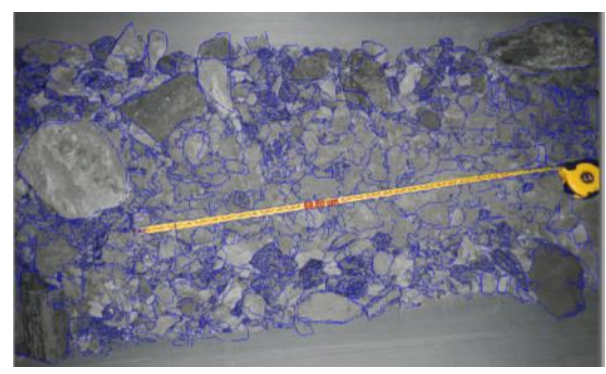

Figure 3. Photo fixation of rocks from the bottom undercutting, destroyed by KA-200 shearer at the exit of the rock mass from the 912 longwall face

\subsection{Research on granulometric composition and loosening coefficient of mine rocks in laboratory conditions}

Mine rocks, sampled at the surface technological complex for sorting raw coal, contain coarse fractions, mainly 100-200 mm, due to the ingress of rocks from the drifting face into a single stream. The laboratory jaw crusher is used to recreate the granulometric composition of rocks in laboratory conditions, similar to that destroyed by KA-200 shearer during stope operations. Based on the obtained data on the granulometric characteristics of the destroyed rock, using a software package, after sieve analysis in laboratory conditions and after crushing, dispersion into separate fractions of 0-5, 5-10, 10-35, $35-50,50-60,60-100$ and $100-140 \mathrm{~mm}$ is performed.

Then, the loosening coefficient of each rocks fraction is studied, which characterizes the degree of loosening the rocks and shows how many times the volume of the loosened 
rock exceeds the volume occupied by it in the mass. This coefficient is important in the technology of backfilling of the mined-out area, as it allows estimating the real volumes of destroyed rocks that can be placed.

The task of determining the coefficient of loosening of destroyed rocks in laboratory conditions was solved through the mass parameter. The rock loosening coefficient is determined as the ratio of the mass of the rock capacity with real density to the mass of the same rock capacity in the loosened state. The bulk density of destroyed rocks was determined as the weight of rocks in a given volume. To determine the loosening coefficient, a laboratory plastic container with a size of $20.5 \times 13.4 \times 10.3 \mathrm{~cm}$ and a volume of $2830 \mathrm{~cm}^{3}$ is used. The container is filled in turn with separately dispersed rock fractions $0-5,5-10,10-35,35-50,50-60,60-100$ and $100-140 \mathrm{~mm}$. Each container with fractions is weighed to fix the net weight. With a container volume of $2830 \mathrm{~cm}^{3}$ and a real rock density in the mass of $2.2 \mathrm{~g} / \mathrm{cm}^{3}$, its weight is $6226 \mathrm{~g}$. The laboratory balance such as VW-10 LN LED up to $10 \mathrm{~kg}$ with accuracy of $2 \mathrm{~g}$ is used.

Then, all the rock fractions are mixed according to the distribution of their specific composition obtained in the program, and a free-flowing rock mixture is formed, similar to the rocks destroyed by KA-200 shearer during the stope operations to determine the overall loosening coefficient.

\section{Results and discussion}

The quality of the backfill material from mine rocks is determined by important parameters such as the loosening coefficients, porosity and shrinkage during filling. The loosening coefficient allows not only to assess the actual volumes of filling the backfill material from mine rocks, but also the limit of its possible compaction, in terms of the coefficient of the destroyed rocks porosity. To determine these parameters, the primary task is to determine the granulometric composition of rocks, which is performed by laboratory research.

The granulometric composition of the destroyed rocks of the seam bottom can depend on the type of shearer used, as well as the arrangement of the cutters on the auger. In our research, the seam bottom rocks are destroyed by the augers of KA-200 shearer, which are drums with a vertical axis of rotation, equipped with KPD04.06.010 cutter holders of the 10 type with PK32/70.000 tangential rock-destruction cutters with a boltless fastening. Photo fixation of destroyed rocks on a belt conveyor of the 912 longwall face stope makes it possible using the WipFrag software package to obtain their granulometric characteristic, shown in Figure 4. The distribution of the destroyed rocks fraction share is summarized in Table 2.

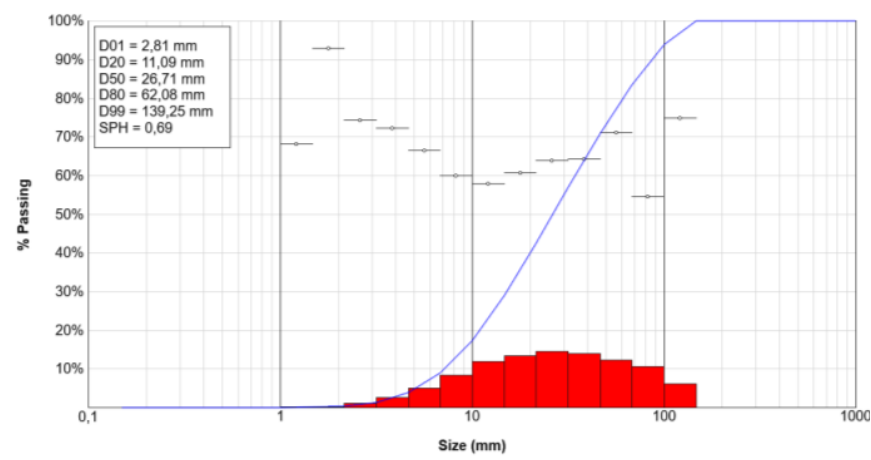

Figure 4. Distribution of the granulometric composition of the bottom undercutting rocks in the 912 longwall face stope
Table 2. Granulometric composition of the seam bottom rocks destroyed by $K A-200$ shearer

\begin{tabular}{cccccccc}
\hline $\begin{array}{c}\text { Fraction, } \\
\mathrm{mm}\end{array}$ & $0-5$ & $5-10$ & $10-35$ & $35-50$ & $50-60$ & $\begin{array}{c}60- \\
100\end{array}$ & $\begin{array}{c}100- \\
140\end{array}$ \\
\hline Share, \% & 3.95 & 13.3 & 42.75 & 14.9 & 5.5 & 13.1 & 6.5 \\
\hline
\end{tabular}

Analysis of the data in Table 2 shows that $75 \%$ of destroyed rocks contain fractions up to $50 \mathrm{~mm}$ in size, which may well be suitable as a backfill material with possible mechanical and vibration backfilling, and do not require a preliminary crushing stage, as in the case of pneumatic backfilling. With a decrease in the granulometric composition of the backfill material, its shrinkage proportionally decreases. Therefore, the predominant amount of fraction up to $50 \mathrm{~mm}$ can have a positive effect on the backfill material deformation characteristics.

Each fraction of mine rocks of 0-5, 5-10, 10-35, 35-50, $50-60,60-100$ and $100-140 \mathrm{~mm}$, filled into a laboratory container is weighed to determine the degree of its filling, which is presented in Figures 5 and 6. Experimental data are summarized in Table 3. Based on the experimental data, the dependence of the change in the loosening coefficient of mine rocks depending on their fractional composition has been obtained, which is shown in Figure 7.

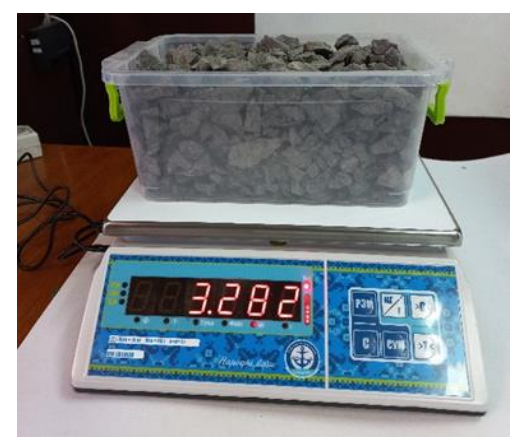

Figure 5. Weighing the rock fractions in the laboratory container
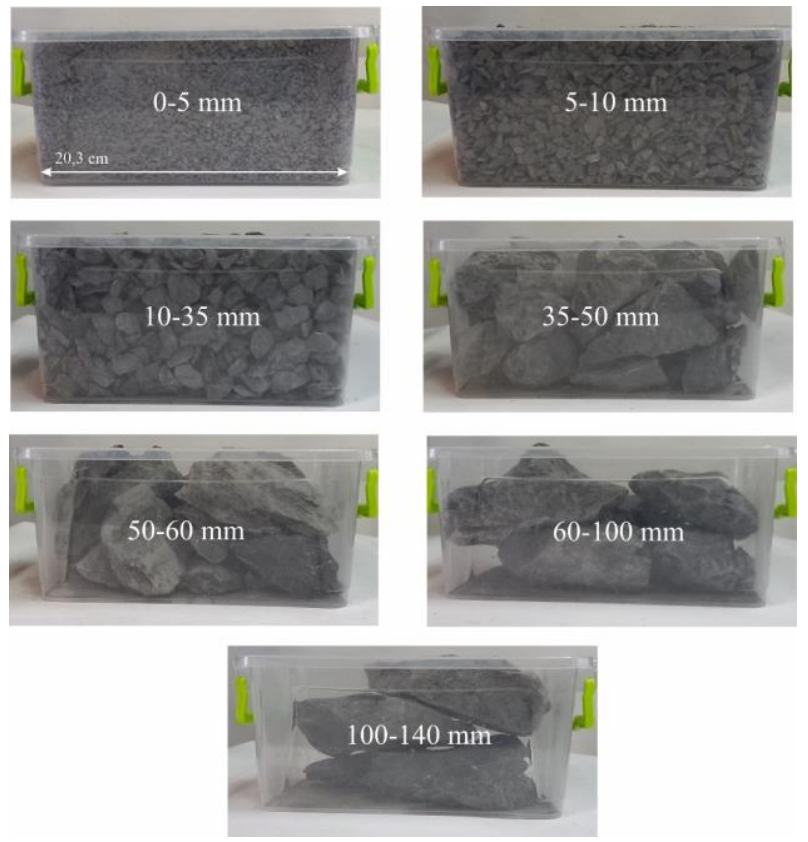

Figure 6. Studying the degree of filling a laboratory container with rocks of fractions 0-5, 5-10, 10-35, 35-50, 50-60, 60-100 and 100-140 $\mathrm{mm}\left(V=2830 \mathrm{~cm}^{3}\right)$ 
Table 3. Experimental data of weighing the rock fractions to determine the loosening coefficient

\begin{tabular}{|c|c|c|c|c|c|c|c|}
\hline Fraction, $\mathrm{mm}$ & $0-5$ & $5-10$ & $10-35$ & $35-50$ & $50-60$ & $60-100$ & $100-140$ \\
\hline $\begin{array}{l}\text { Weight of the container with } \\
\text { rock at real density, g }\end{array}$ & & & & 6223 & & & \\
\hline $\begin{array}{l}\text { Weight of the container with } \\
\text { rock of different fractions, } g\end{array}$ & 3856 & 3326 & 3174 & 3074 & 2892 & 2802 & 2672 \\
\hline Container volume, $\mathrm{cm}^{3}$ & & & & 2830 & & & \\
\hline Bulk density, $\mathrm{g} / \mathrm{sm}^{3}$ & 1.36 & 1.17 & 1.12 & 1.09 & 1.02 & 0.99 & 0.95 \\
\hline Loosening coefficient & 1.61 & 1.87 & 1.99 & 2.15 & 2.18 & 2.22 & 2.32 \\
\hline
\end{tabular}

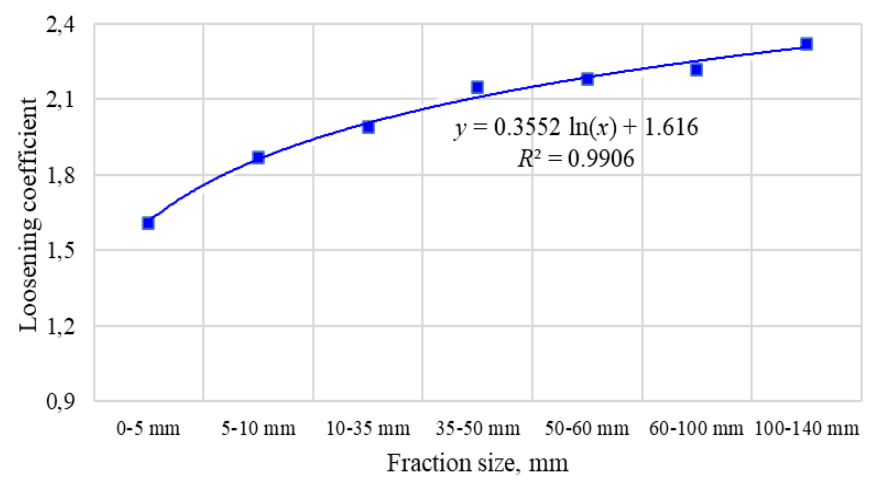

Figure 7. Dependence of the change in the loosening coefficient of undercutting rocks with different fractional composition

Analysis of Figure 7 shows that the loosening coefficient of mine rocks destroyed in the stope face by KA-200 shearer changes according to the logarithmic dependence of the form $y=0.3552 \ln (x)+1.616$ on their granulometric composition, while the approximation reliability is 0.99 .

It should be noted that the loosening coefficient within fractions of $0-50 \mathrm{~mm}$ increases by $33 \%$ and fractions of $50-140 \mathrm{~mm}-$ by $8 \%$. Using the data on the loosening coefficient, it is possible to control the granulometric characteristics of the backfill material in order to achieve the maximum backfill mass density and the completeness of filling the mined-out area. After determining the loosening coefficient of each rock fraction, they are mixed in accordance with a certain percentage to recreate a free-flowing mine rock mixture similar to that destroyed by KA-200 shearer in mine conditions. A mixture of mine rocks with fractions of 0$140 \mathrm{~mm}$ is also weighed and the degree of filling the laboratory container with it is measured (Fig. 8).

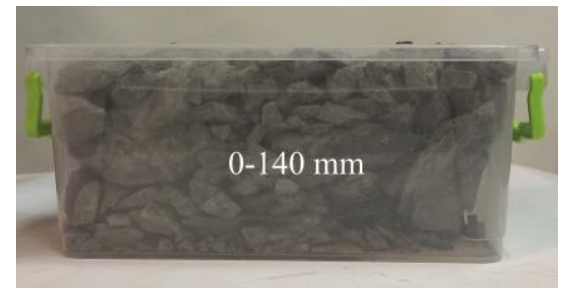

Figure 8. Studying the degree of filling a laboratory container with mixture of destroyed rocks with fractions of 0-140 $\mathrm{mm}$ $\left(V=2830 \mathrm{~cm}^{3}\right)$

The weight of the laboratory container with mine rock fractions of $0-140 \mathrm{~mm}$ is $3620 \mathrm{~g}$, and taking into account the weight of the rocks $-6223 \mathrm{~g}$ with the real density of the same volume, the loosening coefficient is $k_{1}=1.7$ and bulk density is $1.27 \mathrm{~g} / \mathrm{sm}^{3}$. The loosening coefficient of mine rocks and bulk density is linearly related to the voidness, which is indicator of the quantity of voids between fractions of destroyed rocks. If to know the emptiness of the backfill mass from mine rocks, it is possible to determine the limit to which it can be compacted. For practical purposes, with a sufficient degree of accuracy, the value of the voidness can be determined by the formula:

$P=\left(1-\frac{\gamma_{b . d}}{\gamma_{r . d .}}\right) \cdot 100, \%$,

where:

$\gamma_{b . d .}-$ bulk density destroyed rocks, $\mathrm{g} / \mathrm{cm}^{3}$;

$\gamma_{\text {r.d. }}-$ real density of rock mass, $\mathrm{g} / \mathrm{cm}^{3}\left(\gamma_{\text {r.d. }}=2.2 \mathrm{~g} / \mathrm{cm}^{3}\right)$.

The relationship of the main parameters of the destroyed rocks with their fractional composition is presented in Table 4, and their graphic interpretation is shown in Figure 9.

Table 4. Relationship between the loosening coefficient, bulk density and voidness of destroyed rocks

\begin{tabular}{ccccccccc}
\hline Parameter & \multicolumn{4}{c}{ Fraction, mm } & \multicolumn{3}{c}{ Mixture of rocks } \\
\cline { 2 - 7 } & $0-5$ & $5-10$ & $10-35$ & $35-50$ & $50-60$ & $60-100$ & $100-140$ \\
\hline Bulk density, $\mathrm{g} / \mathrm{sm}^{3}$ & 1.36 & 1.17 & 1.12 & 1.09 & 1.02 & 0.99 & 0.95 \\
\hline Loosening coefficient & 1.61 & 1.87 & 1.99 & 2.15 & 2.18 & 2.22 & 2.32 \\
\hline Voidness, $\%$ & 39.0 & 47.0 & 49.1 & 50.5 & 53.7 & 55.0 & 56.9 & 1.28 \\
\hline
\end{tabular}

In our case, the bulk density of the destroyed rocks (0-140 mm) using the KA-200 combine is $1.28 \mathrm{~g} / \mathrm{cm}^{3}$, the loosening coefficient is 1.7 , and the voidness and the maximum margin for compaction of the backfill mass from destroyed rocks is $41.9 \%$.

From a practical point of view, the loosening coefficient of mine rocks, when using them as a backfill material, and taking into account the known cavities in the mined-out area, formed during mining of coal seam, allows to assess the volumes of their possible placement. The placement of rocks in the mined-out area can be either in the form of a simple leaving of mine rocks without compaction, or in the formation of a compacted backfill mass by a mechanical method.

For the conditions of the average longwall face in the Heroiiv Kosmosu Mine, PJSC "DTEK Pavlohradvuhillia", the balance of cavities formed during coal mining in the longwall face, as well as the volume of backfill material from undercutting the rocks, using the selective technology and leaving the rocks in the mined-out area, has approximately been estimated. Furthermore, this technology was developed with the participation of the authors of this research [2], [34]. 


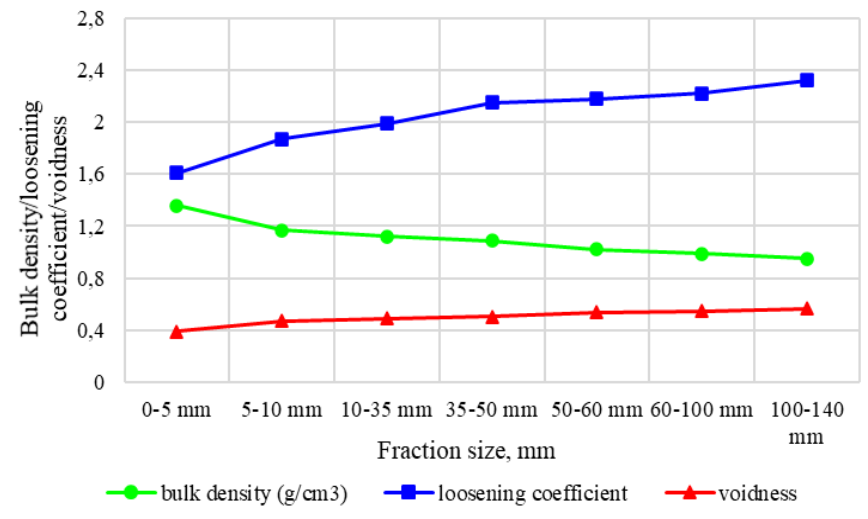

Figure 9. Graphical dependence of the coefficient of loosening, bulk density and voidness of destroyed rocks from their fractional composition

An assessment has been made of how much mine rocks of undercutting can potentially be placed in a mined-out area of a longwall face or in the gobed mine workings using selective mining technology. Selective technology provides for the first-priority mining of the strip along the coal seam with an average geological thickness of $0.87 \mathrm{~m}$ and mining of a bottom rock bench with a thickness of $0.2 \mathrm{~m}$ during the reverse movement of a shearer along the face and the subsequent placement of rocks in the mined-out area using a backfilling horizontal-closed belt conveyor. Next, the volumes of formed cavities and mine rocks are assessed:

- the formed cavities of the mined-out area: the longwall face length is $250 \mathrm{~m}$, the extracting seam thickness is $1.07 \mathrm{~m}$, the convergence value of roof and bottom rocks of the seam is $0.2 \mathrm{~m}$ ( $m$-extracting seam thickness, $\mathrm{m})$, and the daily longwall face advance is $2.5 \mathrm{~m}$. The volume of the formed cavities in the mined-out area is $530 \mathrm{~m}^{3}$;

- the formed cavities of the gobed mine workings: the daily longwall face advance is $2.5 \mathrm{~m}$, the finished crosssection of mine working is $15.0 \mathrm{~m}^{2}$, reduced cross-section in the zone of active displacements behind the longwall face is $0.7 S$ ( $S$-cross-sectional area of mine working); haulage roadway and ventilation drift are gobed. The volume of the formed cavities in the gobed mine workings is $45 \mathrm{~m}^{3}$;

- the volume of formed mine rocks of undercutting is $215 \mathrm{~m}^{3}$ with a longwall face length of $250 \mathrm{~m}$, extracting rock bench thickness of $0.2 \mathrm{~m}$, a daily longwall face advance of $2.5 \mathrm{~m}$ and a rock loosening coefficient of 1.7.

The results of comparing the volumes of cavities and mine rocks are shown in the diagram (Fig. 10).

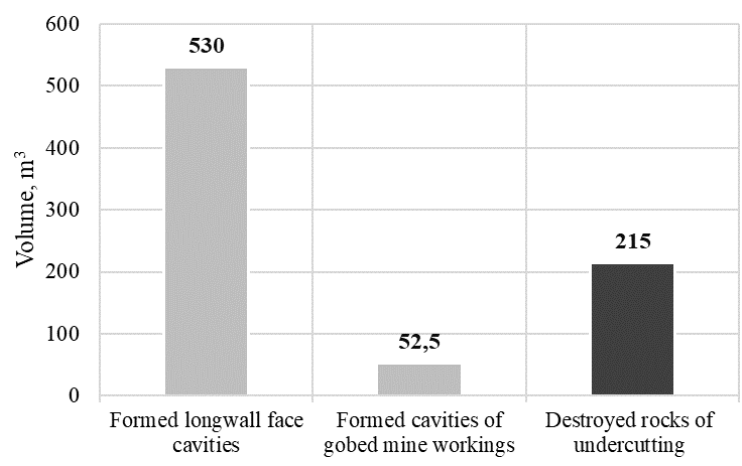

Figure 10. Diagram for comparing the daily volumes of the formed cavities and longwall face mine rocks with a selective mining technology
Analysis of Figure 10 shows that the volume of undercutting rocks destroyed by the shearer and used as backfill material is insufficient to completely fill the cavities of the minedout area of the longwall face. In this case, the degree of filling the mined-out area is $40 \%$. The placement of rocks in this case is like the usual leaving of rocks in the mined-out area. Complete backfilling of the mined-out area can be achieved due to certain improvements in the technology of selective coal mining with backfilling. It is advisable to form in the mined-out area parallel to the face line through one rock strips of the backfill mass, compacting it with vibration and mechanical action. In this case, the volume of undercutting rocks is enough to backfill up to $90 \%$ of the seam thickness. The volume of destroyed undercutting rocks is 4 times greater than the volume of cavities in the gobed drifts following the longwall face. There is also a variant of backfilling the cavities of the gobed mine workings with mine rocks of undercutting, and the rest of the mine rocks are placed in the mined-out area of the longwall face. However, the degree of filling decreases to $30 \%$.

In this research, the granulometric composition and loosening coefficient are studied of mine rocks, which are formed as a result of undercutting the seam bottom in the stope face and used as a backfill material or production waste for leaving in the mine-out area. An analytical assessment of the volumes of the formed cavities, as well as the prospects for their filling with mine rocks is presented.

Further research can serve as a basis for determining the rational parameters for the formation and placement of backfill masses during complex-mechanized selective mining of coal seams using various methods of backfilling operations.

\section{Conclusions}

A combined methodology for studying the granulometric composition of destroyed undercutting rocks has been developed on the basis of mine and laboratory research using information technologies, when the collection and delivery of experimental samples from the stope face is complicated by production conditions.

It has been determined that the loosening coefficient of mine rocks destroyed in the stope face by KA-200 shearer changes according to the logarithmic dependence on their granulometric composition. The loosening coefficient within fractions $0-50 \mathrm{~mm}$ increases by $33 \%$ and fractions $50-140 \mathrm{~mm}$ - by $8 \%$. Using the data on the loosening coefficient, it is possible to control the granulometric characteristics of the backfill material in order to achieve the maximum backfill mass density and the completeness of filling the mined-out area.

It has been found that $75 \%$ of destroyed rocks contain fractions up to $50 \mathrm{~mm}$ in size, which may well be suitable as a backfill material with possible mechanical and vibration backfilling, and do not require a preliminary crushing stage, as in the case of pneumatic backfilling.

It has been determined that the destroyed rocks in the face within fractions of $0-140 \mathrm{~mm}$ have a bulk density of $1.28 \mathrm{~g} / \mathrm{cm}^{3}$, loosening coefficient of 1.7 , the voidness of and the maximum reserve for the backfill mass compaction with mine rocks is $41.9 \%$.

An analytical assessment of the volumes of the formed cavities and mine rocks has been performed. It has been determined that the volume of undercutting rocks destroyed by 
the shearer and used as backfill material is insufficient to completely fill the cavities of the mined-out area of the longwall face. In this case, the degree of filling the mined-out area is $40 \%$. Complete backfilling of the mined-out area can be achieved due to certain improvements in the technology of selective coal mining with backfilling. It is advisable to form in the mined-out area parallel to the face line through one rock strips of the backfill mass, compacting it with vibration and mechanical action. In this case, the degree of filling the minedout area can approach $90 \%$ of the seam thickness. The volume of destroyed undercutting rocks is 4 times greater than the volume of cavities in the gobed drifts following the longwall face. The cavities of the gobed mine workings can also be filled with mine rocks of undercutting, and the rest of the mine rocks can be placed in the mined-out area of the longwall face. In this case, the degree of filling decreases to $30 \%$.

\section{Acknowledgements}

The authors express their gratitude to Vasyl Snihur, Candidate of Technical Sciences, Director of Mine Administration Heroiiv Kosmosu, PJSC "DTEK Pavlohradvuhillia", for help and assistance in conducting mine measurements of the granulometric composition of rocks. The work has been performed as part of the research work of young scientists, funded by the Ministry of Education and Science of Ukraine No. $0120 \mathrm{U} 101099$.

\section{References}

[1] Xiong, Y., Kong, D., Wang, Y., Liu, Q., \& Gong, Y. (2021). Technology and performance analysis of preventing surface subsidence by sealing and backfilling the goaf with Urban waste. Geotechnical and Geological Engineering, 1-15. https://doi.org/10.21203/rs.3.rs-348022/v1

[2] Petlovanyi, M.V., Malashkevych, D.S., \& Sai, K.S. (2020). The new approach to creating progressive and low-waste mining technology for thin coal seams. Journal of Geology, Geography and Geoecology, 29(4), 765-775. https://doi.org/10.15421/112069

[3] Cui, X., Zhao, Y., Wang, G., Zhang, B., \& Li, C. (2020). Calculation of residual surface subsidence above abandoned longwall coal mining. Sustainability, 12(4), 1528. https://doi.org/10.3390/su12041528

[4] Ganushevych, K., Sai, K., \& Korotkova, A. (2014). Creation of gas hydrates from mine methane. (2014). Progressive Technologies of Coal, Coalbed Methane, and Ores Mining, 517-522. https://doi.org/10.1201/b17547-85

[5] Popovych, V., Bosak, P., Petlovanyi, M., Telak, O., Karabyn, V., \& Pinder, V. (2021). Environmental safety of phytogenic fields formation on coal mines tailings. Series of Geology and Technical Sciences, 2(446), 129-136. https://doi.org/10.32014/2021.2518-170x.44

[6] Cardoso, A.T., \& Fan, F.M. (2021). A first evaluation of water resource conditions after an environmental reclamation effort at a former degraded coal mining area in Southern Brazil. Environmental Monitoring and Assessment, 193(10), 632. https://doi.org/10.1007/s10661-021-09393-4

[7] Zhiznin, S.Z., \& Cherechukin, A.V. (2020). Factors of development and introduction of clean coal-mining technologies in the world economy. Mining Informational and Analytical Bulletin, (6), 27-37. https://doi.org/10.25018/0236-1493-2020-6-0-27-37

[8] Barbara, A., \& Sluder, L. (2019). Impact of fuel and energy complex on sustainable development of mineral extracting regions: The world experience. E3S Web of Conferences, (105), 04007. https://doi.org/10.1051/e3sconf/201910504007

[9] Qing, G., Luo, Y., Huang, W., Wang, W., Yue, Z., Wang, J., Li, Q., Jiang, S., \& Sun, S. (2021). Driving factors of energy consumption in the developed regions of developing countries: A case of Zhejiang Province, China. Atmosphere, (12), 1196. https://doi.org/10.3390/atmos12091196

[10] Sakhno, I., Nosach, A., \& Beletskaya, L. (2015). Stress-and-strain state of rock mass around the working behind the longwall face. New Developments in Mining Engineering 2015: Theoretical and Practical Solutions of Mineral Resources Mining, 133-138. https://doi.org/10.1201/b19901-25

[11] Zhang, C., Tu, S., \& Zhao, Y. (2019). Compaction characteristics of the caving zone in a longwall goaf: A review. Environmental Earth Sciences, 78(1), 27. https://doi.org/10.1007/s12665-018-8037-7
[12] Malashkevych, D., Poimanov, S., Shypunov, S., \& Yerisov, M. (2020). Comprehensive assessment of the mined coal quality and mining conditions in the Western Donbas mines. E3S Web of Conferences, (201), 01013. https://doi.org/10.1051/e3sconf/202020101013

[13] Pivnyak, G.G., Pilov, P.I., Bondarenko, V.I., Surgai, N.S., \& Tulub, S.B. (2005). Development of coal industry: The part of the power strategy in the Ukraine. Gornyi Zhurnal, (5), 14-17.

[14] Bondarenko, V.I., Griadushchiy, Y.B., Dychkovskiy, R.O., Korz, P.P., \& Koval, O.I. (2007). Advanced experience and direction of mining of thin coal seams in Ukraine. Technical, Technological and Economic Aspects of Thin-Seams Coal Mining International Mining Forum 2007, 1-7.

[15] Regional report on the state of the environment in the Dnipropetrovsk region in 2019. (2020). Dnipro, Ukraine: Department of Ecology and Natural Resources of the Dnipropetrovsk Regional State Administration, $320 \mathrm{p}$.

[16] Petlovanyi, M.V., \& Medianyk, V.Yu. (2018). Assessment of coal mine waste dumps development priority. Naukovyi Visnyk Natsionalnoho Hirnychoho Universytetu, (4), 28-35. https://doi.org/10.29202/nvngu/2018-4/3

[17] Zhao, Y., Liu, L., Wen, D., Zhang, X., Huan, C., Zhang, B., \& Wang, X. (2022). Recycling waste material for backfill coupled heat exchanger systems in underground stopes of mines. Energy and Buildings, (256), 111703. https://doi.org/10.1016/j.enbuild.2021.111703

[18] Bazaluk, O., Petlovanyi, M., Lozynskyi, V., Zubko, S., Sai, K., \& Saik, P. (2021). Sustainable underground iron ore mining in Ukraine with backfilling worked-out area. Sustainability, 13(2), 834. https://doi.org/10.3390/su13020834

[19] Behera, S.K., Mishra, D.P., Singh, P., Mishra, K., Mandal, S.K., Ghosh, C.N., Mandal, P.K. (2021). Utilization of mill tailings, fly ash and slag as mine paste backfill material: Review and future perspective. Construction and Building Materials, (309), 125120. https://doi.org/10.1016/j.conbuildmat.2021.125120

[20] Petlovanyi, M.V., Zubko, S.A., Popovych, V.V., \& Sai, K.S. (2020). Physico-chemical mechanism of structure formation and strengthening in the backfill massif when filling underground cavities. Voprosy Khimii $i$ Khimicheskoi Technologii, (6), 142-150. https://doi.org/10.32434/0321-4095-2020-133-6-142-150

[21] Mashifana, T., \& Sithole, T. (2021). Clean production of sustainable backfill material from waste gold tailings and slag. Journal of Cleaner Production, (308), 127357. https://doi.org/10.1016/j.jclepro.2021.127357

[22] Petlovanyi, M., \& Mamaikin, O. (2019). Assessment of an expediency of binder material mechanical activation in cemented rockfill. ARPN Journal of Engineering and Applied Sciences, 14(20), 3492-3503.

[23] Jiang, H., Cao, Y., Huang, P., Fang, K., \& Li, B. (2015). Characterisation of coal-mine waste in solid backfill mining in China. Mining Technology, 124(1), 56-63. https://doi.org/10.1179/1743286315y.0000000002

[24] Zhang, J., Li, M., Taheri, A., Zhang, W., Wu, Z., \& Song, W. (2019). Properties and application of backfill materials in coal mines in China. Minerals, 9(1), 53. https://doi.org/10.3390/min9010053

[25] Dychkovskyi, R., Shavarskyi, J., Cabana, E.C., \& Smoliński, A. (2019). Characteristic of possible obtained products during the well underground coal gasification. Solid State Phenomena, (291), 52-62. https://doi.org/10.4028/www.scientific.net/ssp.291.52

[26] Petlovanyi, M, Medianyk, V., Sai, K., Malashkevych, D., \& Popovych, V. (2021). Geomechanical substantiation of the parameters for coal auger mining in the protecting pillars of mine workings during thin seams development. ARPN Journal of Engineering and Applied Sciences, 16(15), 1572-1582.

[27] Bahri Najafi, A., Saeedi, G.R., \& Ebrahimi Farsangi, M.A. (2014). Risk analysis and prediction of out-of-seam dilution in longwall mining. International Journal of Rock Mechanics and Mining Sciences, (70), 115-122. https://doi.org/10.1016/j.ijrmms.2014.04.015

[28] Kosarev, I.V. (2016). Innovatsionnye napravleniya v sozdanii gornoshakhtnogo oborudovaniya, obespechivayushchego povyshenie effektivnosti dobychi uglya. Vestnik Donetskogo Natsional'nogo Tekhnicheskogo Universiteta, (6), 12-18.

[29] Zhu, X., Guo, G., Liu, H., \& Yang, X. (2019). Surface subsidence prediction method of backfill-strip mining in coal mining. Bulletin of Engineering Geology and the Environment, 78(8), 6235-6248. https://doi.org/10.1007/s10064-019-01485-3

[30] Sokolov, A.S., \& Potapov, V.V. (2014). Tekhniko-ekonomicheskaya effektivnost' tekhnologii podzemnogo ugleobogashcheniya. Gornyy Zhurnal, (1), 42-46.

[31] Potapov, V.V. (2006). Tekhnologicheskie skhemy upravleniya kachestvom uglya pri podzemnoy dobyche po friktsionnym kharakteristikam. Gornyy Informatsionno-Analiticheskiy Byulleten', (5), 193-195.

[32] Byzylo, V., Koshka, O., Poymanov, S., \& Malashkevych, D. (2015). Resource-saving technology of selective mining with gob backfilling. New Developments in Mining Engineering 2015: Theoretical and Practi- 
cal Solutions of Mineral Resources Mining, 485-491. https://doi.org/10.1201/b19901-84

[33] Petlovanyi, M., Malashkevych, D., Sai, K., \& Zubko, S. (2020). Research into balance of rocks and underground cavities formation in the coal mine flowsheet when mining thin seams. Mining of Mineral Deposits, 14(4), 66-81. https://doi.org/10.33271/mining14.04.066

[34] Malashkevych, D.S., Petlovanyi, M.V., \& Poimanov, S.M. (2021). Sposib zakladky vyroblenoho prostoru. Patent \#147810. Ukraina, $4 \mathrm{~s}$.

\section{Дослідження гранулометричного складу шахтних порід} як закладного матеріалу виробленого простору вугільних шахт

\section{М. Петльований, Д. Малашкевич, К. Сай, С. Булат, В. Попович}

Мета. Визначення гранулометричних характеристик та коефіцієнта розпушення шахтних порід, утворених у процесі очисних робіт від присікання порід підошви, як потенційного закладного матеріалу на основі комплексу шахтних і лабораторних досліджень.

Методика. Для проведення досліджень використана комплексна методика, яка складалася з фотозйомки маси зруйнованих порід присікання порід підошви у шахтних умовах, цифрової обробки та визначення гранулометричного складу в програмному пакеті, відбору проб шахтних порід на поверхневому комплексі, відтворення гранулометричного складу аналогічно натурним шахтним умовам у лабораторії. Для визначення гранулометричного складу та коефіцієнта розпушення використовувалися ситовий аналіз, лабораторні ваги, лабораторна ємність.

Результати. Виявлено взаємозв'язок гранулометричного складу та коефіцієнта розпушення порід, який у межах фракцій 0-50 мм зростає на 33\%, а фракцій 50-140 мм - на 8\%. Встановлено, що зруйновані породи в очисних вибоях у межах фракцій

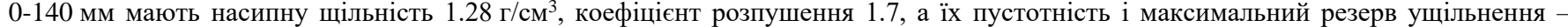
41.9\%. Надана аналітична оцінка обсягів утворених пустот виробленого простору лави та виробок, що погашаються, а також перспектив і повноти їх заповнення шахтними породами.

Наукова новизна. Встановлено, що коефіцієнт розпушення шахтних порід, зруйнованих в очисному вибої очисним комбайном КА-200, змінюється за логарифмічною залежністю від їхнього гранулометричного складу, що дає можливість управляти гранулометричними характеристиками закладного матеріалу для досягнення максимальної щільності закладного масиву.

Практична значимість. Дослідження надалі слугуватимуть базою для встановлення раціональних параметрів формування та розміщення закладних масивів при комплексно-механізованому селективному вийманні вугільних пластів різними засобами здійснення закладних робіт.

Ключові слова: шахтні породи, присікання порід, очисний вибій, очисний комбайн, гранулометричний склад, коефіцієнт розпушення, підземні пустоти, закладний матеріал

\section{Исследование гранулометрического состава шахтных пород как закладочного материала выработанного пространства угольных шахт}

\section{М. Петлёваный, Д. Малашкевич, Е. Сай, Е. Булат, В. Попович}

Цель. Определение гранулометрических характеристик и коэффициента разрыхления шахтных пород, образованных в процессе очистных работ от присечки пород почвы, как потенциального закладочного материала на основе комплекса шахтных и лабораторных исследований.

Методика. Для проведения исследований использована комплексная методика, которая состояла из фотосъемки массы разрушенных пород присечки пород почвы в шахтных условиях, цифровой обработки и определения гранулометрического состава в программном пакете, отбора проб шахтных пород на поверхностном комплексе, воссоздания гранулометрического состава аналогично натурным шахтным условиям в лаборатории. Для определения гранулометрического состава и коэффициента разрыхления использовались ситовый анализ, лабораторные весы, лабораторная емкость.

Результаты. Выявлена взаимосвязь гранулометрического состава и коэффициента разрыхления пород, который в пределах фракций 0-50 мм возрастает на 33\%, а фракций 50-140 мм - на 8\%. Установлено, что разрушенные породы в очистных забоях в пределах фракций 0-140 мм обладают насыпной плотностью 1.28 г/см³, коэффициентом разрыхления 1.7 , а их пустотность и максимальный резерв уплотнения - 41.9\%. Дана аналитическая оценка объемов образованных пустот выработанного пространства лавы и погашаемых выработок, а также перспектив и полноты их заполнения шахтными породами.

Научная новизна. Установлено, что коэффициент разрыхления шахтных пород, разрушенных в очистном забое очистным комбайном КА-200, изменяется по логарифмической зависимости от их гранулометрического состава, что дает возможность управлять гранулометрическими характеристиками закладочного материала для достижения максимальной плотности закладочного массива.

Практическая значимость. Исследования в дальнейшем послужат базой для установления рациональных параметров формирования и размещения закладочных массивов при комплексно-механизированной селективной выемке угольных пластов различными средствами производства закладочных работ.

Ключевые слова: шахтные породы, присечка пород, очистной забой, очистной комбайн, гранулометрический состав, коэффиичиент разрыхления, подземные пустоты, закладочный материал 